УДК 37.013.43:811.112.2

DOI:

Ірина Западинська, кандидат педагогічних наук, доиент кафедри іноземної філології та перекладу Вінницького торговельно-економічного інституту КНТЕУ

\title{
ПРОБЛЕМА ПОСЛІДОВНОСТІ У ФОРМУВАННІ ІНШОМОВНОЇ КОМУНІКАТИВНОӤ КОМПЕТЕНТНОСТІ НА ПОЧАТКОВОМУ ЕТАПІ ВИВЧЕННЯ IHОЗЕМНОЇ МОВИ
}

Іншомовна комунікачія можлива за умови володіння суб 'єктами іншомовного спілкування мовою як засобом комунікації. Рівень сформованості іншомовної комунікативної компетентності суб'єктів виступає визначальним фактором, щуо обумовлює рівень ефективності комунікативного прочесу в иілому. Практична мета навчання іноземних мов полягає в оволодінні іншомовною комунікативною компетентністю, яка на сучасному етапі виступає важливим структурним компонентом професійної компетентності майбутнього вчителя вищої школи. Іншомовну комунікативну компетентність визначають як сукупність знань, умінь та навичок, необхідних для ефективного здійснення іншомовної комунікаиії у різних сферах діяльності людини, зокрема у професійній діяльності.

Ключові слова: комунікативна компетентність; іноземні мови; гуманітарна освіта; послідовність, мовна поведінка.

Jim. 6.

Iryna Zapadynska, Ph.D.(Pedagogy), Associate Professor of the Foreign Philology and Translation Department Vinnytsta Institute of Trade and Economics Kyiv National Trade and Economics University

\section{THE PROBLEM OF CONSISTENCY IN FORMING OF FOREIGN COMMUNICATIVE COMPETENCE ON THE INITIAL STAGE OF LANGUAGE STUDY}

The foreign-language communication is possible subject to the possession of foreign language communication by subjects as a means of communication. The level of formation of foreign language communicative competence of subjects is the determining factor that determines the level of efficiency of the communicative process in general. The practical purpose of teaching foreign languages is to master the foreign language communicative competence, which at present is an important structural component of the professional competence of the future teacher of elementary school. Inter-language communicative competence is defined as a set of knowledge, abilities and skills necessary for the effective implementation of foreign communication in various spheres of human activity, in particular, into the professional activities. The following components are the part of the foreign language communicative competence: the Gnostic (the system of knowledge of the essence, features and style of foreign communication, in particular professional); communicative (communicative, expressive and perceptive-reflexive skills; speech culture); emotional (positive setting for communication, developed empathy and reflection, high level of identification with relevant professional and social roles). The other language communicative competence is considered, on the one hand, as the ability to communicate in other languages, correctly using the system of language, speech and stylistic norms, as well as rules of communicative behavior, in accordance with the situation of communication, and on the other hand, as readiness for foreign language communication.

The process of forming a foreign language communicative competence should be aimed not only at equipping future specialists with the system of knowledge, skills and abilities necessary for the effective implementation offoreign communication, but also for the formation of a deeply meaningful, communicative and competent position of the future teacher of the elementary school. The main task of the modern educator is to form a person with such a level of cultural development, which allows you to freely orient and feel comfortable in a variety of communicative situations. Most of all, this is facilitated by the communicative approach, which determines the practical purpose of studying and learning foreign languages, namely: the formation and development of intercultural communicative competence. The communicative purpose in the study of MI is of paramount importance, since it provides for such an organization of activities that is aimed at mastering the students communication in oral (speaking, listening) and writing (reading, writing) forms within certain communicative spheres, subjects of situational broadcasting and on the basis of the learned linguistic and speech material. It is the acquisition of communicative competence that transforms a student from the carrier of academic knowledge to a person who is socially active and is oriented towards socialization in society with a view to the practical use of acquired knowledge.

Keywords: communicative competence; foreign languages; humanitarian education; consistency; linguistic behavior.

П

остановка проблеми.До складуіншомовної комунікативної компетентності входять наступні компоненти: гностичний (система знань про сугність, особливості та стилі іншомовного спілкування, зокрема професійного); комунікативний (комунікативні, експресивні та 


\section{ПРОБЛЕМА ПОСЛДОВНОСТІ У ФОРМУВАННІ ІНШОМОВНОӤ КОМУНІКАТИВНОӦ КОМПЕТЕНТНОСТІ НАПОЧАТКОВОМУ ЕТАПІ ВИВЧЕННЯ ННОЗЕМНОӤ МОВИ}

перцептивно-рефлексивні вміння; культура мовлення); емоційний (позитивна установка на спілкування; розвинуті емпатія та рефлексія; високий рівень ідентифікації з відповідними професійними та соціальними ролями).

Основне завдання сучасного педагога полягає у формуванні особистості 3 таким рівнем культурного розвитку, який дозволяє вільно орієнтуватись і комфортно почуватись у різноманітних комунікативних ситуаціях. Найбільше цьому сприяє комунікативний підхід, який зумовлює практичну мету навчання й вивчення іноземних мов, а саме: формування $\mathrm{i}$ розвиток міжкультурної комунікативної компетенції. Комунікативна мета у вивченні IM $€$ приорітетною, бо вона передбачає таку організацію діяльності, яка спрямована на оволодіння учнями спілкуванням в усній (говоріння, аудіювання) та писемній (читання, письмо) формах у межах визначених комунікативних сфер, тематики ситуативного мовлення та на основі вивченого мовного і мовленнєвого матеріалу. Саме набуття комунікативної компетентності перетворює учня 3 носія академічних знань на людину соціально активну, налаштовануна соціалізацію у суспільстві 3 метою практичного використання набутих знань.

Згідно 3 дидактичним принципом систематичності та послідовності навчальний матеріал 3 основних предметів (мова, математика, природознавство, історія) здебільшого вивчають двічі: у початковій школі (правила, оповідання), у середній - за системним принципом, завдяки чому досягається послідовність навчання: від простого - до складного. Державний компонент змісту сучасної середньої освіти передбачає вивчення іноземної мови, починаючи з початкових класів. У зв'язку 3 цим актуалізується проблема наступності стосовно ще одного предмета - іноземної мови. Оскільки досягнення наступності в шкільній практиці забезпечується методично і психологічно обгрунтованою побудовою програм, підручників, дотриманням послідовності руху від простого до складнішого в навчанні та організації самостійної роботи учнів, виникає нагальна необхідність порушення цілої низки питань, що спрямовані на удосконалення навчального процесу з іноземної мови на різних етапах її вивчення. Одна з таких актуальних проблем - наступність у формуванні іншомовної комунікативної культури учнів початкових класів у процесі вивчення іноземної мови.

Аналіз основних досліджень проблеми.
Існуюча джерельна база 3 проблеми наступності у навчальному процесі представлена різноманітними підходами: - наступність цілей, змісту і методів викладання різних дисциплін у різних типах шкіл (Б. Ананьєв, А. Блаус); - наступність у формуванні системи трудових і професійних знань та навичок в середній школі (Е. Зеєр, Г. Качан); - наступність у формуванні внутрішньої позиції молоді в середній і вищій школі (С. Годник, В. Максимова); - політехнічний аспект і наступність професійної орієнтації учнів у середній школі (Г. Ібрагімов, А. Кивелярг, I. Халліулін та). У нашій публікації ми розглядаємо проблему наступності у контексті дидактичного принципу систематичності та послідовності і суть ії визначаємо тезою: “Кожне нове знання спирається на попереднє і логічно 3 ним пов'язане".

Мета статті полягає в теоретичному обгрунтуванні дидактичної вимоги наступності у формуванні іншомовної комунікативної культури на початковому етапі вивчення іноземної мови.

Виклад основного матеріалу дослідження. Поняття наступності $є$ насамперед філософською категорією, яка у Великому енциклопедичному словнику інтерпретується наступним чином: “'Зв'язок між явищами у процесі розвитку, коли нове, замінюючи старе, зберігає в собі деякі його елементи. Наступність носить об'єктивний характер, проявляючись у природі, суспільстві і пізнанні” [2, 514]. У психолого-педагогічній літературі наводяться різноманітні трактування наступності. Так, наступність в освіті - це безперервний зв'язок між різними етапами i стадіями в історичному розвитку освітньої теорії і практики, який базується на збереженні і поступовому збагаченні загальних традицій $\mathrm{i}$ більш приватного позитивного досвіду, на їхньому постійному якісному оновленні з урахуванням змін, що відбуваються в житті суспільства, і нового змісту освітніх потреб $[5,306]$. Наступність у навчанні, відповідно до українського педагогічного словника, це “послідовність і системність у розміщенні навчального матеріалу, зв’язок і узгодженість ступенів та етапів навчальновиховного процесу" [3, 227]. Актуальним є висловлювання Ю. Кустова про те, що одна 3 основних функцій наступності полягає в тому, щоб на цілісність формування особистості конструктивно працювали три педагогічних виміри: минуле, теперішне та майбутнє у своїй взаємодії. Суть прогресивної наступності полягає в удосконаленні теперішнього та в осмисленому програмуванні майбутнього з опорою на минуле, у подальшому розвитку прогресивного i 


\section{ПРОБЛЕМА ПОСЛДОВНОСТІУ ФОРМУВАННІ ІНШОМОВНОӤ КОМУНІКАТИВНОӤ КОМПЕТЕНТНОСТІНАПОЧАТКОВОМУ ЕТАПІ ВИВЧЕННЯ ІНОЗЕМНОӤ МОВИ}

конструктивного з того, що йому передувало. При цьомуфункціонування наступності є універсальним, a iï прояви носять загальнопедагогічний характер [4, 35]. Наступність у навчанні полягає у встановленні необхідного зв'язку і правильного співвідношення між частинами навчального предмета на різних щаблях його вивчення. Наступність при вивченні іноземної мови у початковій школі - це опора на пройдене, використання і подальший розвиток в учнів уже набутих знань, умінь, навичок, які сприяють встановленню, реалізації різноманітних зв'язків наступності, взаємодії старих і нових знань, отриманих на уроках іноземної мови, що у кінцевому результаті створює їх систему, розкриває зміст і основні ідеї різних навчальних тем предмета. Наприклад, у початковій школі у процесі засвоєння іноземної мови створюються умови для ранньої комунікативно-психологічної адаптації молодших школярів до нового мовного світу, для подолання в подальшому психологічних бар'єрів при використанні іноземної мови як засобу спілкування, для розвитку мотивації до подальшого оволодіння іноземною мовою. Окрім того, закладається основа для формування елементарної комунікативної компетенції, i, відповідно, розвиваються елементарні комунікативні уміння в основних видах мовленнєвої діяльності (говорінні, аудіюванні, читанні, письмі), а також елементарні лінгвістичні уявлення і загальнонавчальні уміння.

Важливим завданням вивчення іноземної мови $\epsilon$ формування іншомовної комунікативної культури. Враховуючи те, що в учнів молодших класів невеликий обсяг уваги, такі ж невеликі можливості для осмислення пропонованої інформації, у початковій школі завдання іншомовної культури обмежується засвоєнням елементів мовленнєвого етикету: привітання, прощання, увічливе звертання до співрозмовника, висловлення форм вдячності тощо. Виходячи 3 цих міркувань, при формуванні іншомовної комунікативної культури особливо важливо дотримуватися наступності, чіткої регламентованості і дозування пропонованої інформації. Наприклад, автор навчально-методичного комплексу "Guten Tag!” Н. Басай для реалізації зазначеного завдання для учнів третього класу пропонує ряд мовленнєвих зразків до кожної тематичної частини книги: Das ist ein/eine... Ist das ein/eine...? Stimmt das? - Ja, das stimmt./Nein, das stimmt nicht. Was fehlt? - Das Fahrrad fehlt. Was kostet das? Was möchtest du werden? Ich wünsche dir alles Gute! Ich gratuliere dir zum Geburtstag! - Danke schön! [1]. Мовленнєві зразки подаються невеликими порціями, через що, як нам видається, не заважають засвоєнню іншого лексичного, фонетичного, синтаксичного та граматичного матеріалу. Можемо стверджувати, що принцип наступності витриманий авторкою у всьому циклі підручників “Guten Tag!”, оскільки у доборі навчального матеріалу для кожного класу враховуються знання, уміння і навички з іноземної мови, що були сформовані на попередньому етапі.

На рівні середньої школи діапазон іншомовної комунікативної культури доповнюється умінням вести діалог із співрозмовником на задану тему, коректно ставити запитання, орієнтуватися в особливостях культури носіїв тієї іноземної мови, яка вивчається тощо. Основи іншомовної комунікативної культури, сформовані в учнів на рівні загальноосвітньої школи, доповнюються у процесі вивчення іноземної мови узакладах вищої освіти.

Поняття наступності характеризує також вимоги до знань і умінь учнів на кожному етапі навчання, до форм, методів і прийомів пояснення нового навчального матеріалу і до всієї наступної роботи для його засвоєння. Наступність об'єктивно існує і повинна дотримуватися між частинами, розділами навчального матеріалу. Наприклад, зв'язок між фонетикою, морфологією і синтаксисом - у граматиці іноземної мови. Так, у процесі вивчення синтаксису використовуються знання і прийоми мислення, які сформувалися при вивченні морфології і фонетики, що сприяє активному засвоєнню нового матеріалу.

Формування комунікативної культури на основі наступності повинне охоплювати не тільки окремі навчальні предмети, але й взаємозв'язки між ними. Основою для цього виступають об'єктивні зв'язки між сторонами об'єкта, які вивчаються у різних предметах. У початкових класах при вивченні іноземної мови слід спиратися на вже наявні в учнів знання, уміння і навички, здобуті на уроках з інших навчальних предметів: рідної мови, музики, образотворчого мистецтва, трудового навчання.

Наступність у доборі навчального матеріалу з предмета і способів діяльності для опанування цим навчальним матеріалом здійснюється, зважаючи на два фактори: зміст, логіка відповідної науки та закономірності процесу засвоєння знань.

Дія першого фактора є визначальною для дотримання наступності у побудові навчального предмета: поняття, закони і факти, які складають основний зміст навчального предмета, розташовані в послідовності, яка забезпечує поступове розкриття змісту галузі знань, що вивчається, причому наступне органічно пов'язане з попереднім. 


\section{ПРОБЛЕМА ПОСЛДОВНОСТІ У ФОРМУВАННІ ІНШОМОВНОӤ КОМУНІКАТИВНӦ̈ КОМПЕТЕНТНОСТІ НАПОЧАТКОВОМУ ЕТАПІ ВИВЧЕННЯ ІНОЗЕМНОӤ МОВИ}

Дія другого фактора - закономірностей процесу засвоєння - не дозволяє прямо переносити зміст певної наукової галузі в навчальний предмет, так як потребує дидактичного переосмислення цього змісту. Так, наступність реалізується не тільки в лінійному, але й у концентричному розташуванні навчального матеріалу [6]. Включення кожного компонента навчального предмета "Іноземна мова" у всі більш широкі і глибокі зв'язки дозволяє збагачувати його зміст, однак при цьому слід уникати не виправданих, логічно зайвих повторів.

Принцип наступності виступає також у якості системотворчого фактора. Стосовно іншомовної комунікативної культури він дозволяє розглядати іiі як цілісну систему, виявляти взаємозв'язок між iii основними компонентами, вишукувати приховані резерви для удосконалення i оптимального планування їі подальшого розвитку.

Для досягнення наступності у формуванні комунікативної культури у процесі навчання іноземної мови, окрім її поступового здійснення у змісті, дуже важливим є постійний контакт між учителями різних ступенів навчання, а також попереднє вивчення початкового рівня знань 3 іноземної мови.

Висновки. Таким чином, теоретичне обгрунтування проблеми наступності у контексті дидактичного принципу систематичності та послідовності дозволяє зробити деякі висновки.

1. Наступність передбачає поступовість переходу від однієї ланки освітньої системи до іншої, послідовність зміни рівня вимог до обсягу знань, умінь та навичок, органічний взаємозв'язок змісту, форм і методів навчально-виховного процесу на різних ступенях освіти.

2. Наступність у навчанні - це опора на пройдене, використання і подальший розвиток в учнів уже набутих знань, умінь, навичок, які сприяють встановленню, реалізації різноманітних зв'язків наступності, взаємодії старих і нових знань, отриманих на уроках іноземної мови, що в прикінцевому результаті створює їх систему, розкриває зміст і основні ідеї різних навчальних тем предмета.

3. 3 урахуванням вимог наступності слід укладати. навчальні програми, що передбачають розміщення матеріалу у двох формах: а) лінійній (вивчення нового матеріалу на основі повторення попереднього); б) концентричній (без повторення, на більш високому рівні мислення учнів на кожному наступному уроці $з$ даної теми).

\section{ЛІТЕРАТУРА}

1. Басай Н.П. Добрий день!: Кн. для вчителя / Надія Басай. - К.: Освіта, 2003.- 87 с.

2. Большая советская энциклопедия / Под ред. А.М.Прохорова. - М.: Советская энциклопедия. - 1973. - T. 12. $-875 \mathrm{c}$.

3. Гончаренко С.У. Український педагогічний словник / Семен Гончаренко. - К.: Либідь, 1997. $-374 \mathrm{c}$.

4. Кустов Ю.А. Теоретические основы преемственности профессиональной подготовки молодежи / Ю.А.Кустов. - Казань, 1989. - 367 с.

5. Преемственность в обучении. Энциклопедия профессионального образования: В 3-х т. / Под общ. ред. С.Я.Батышева. - Т.2. - М.: Профессиональное образование, 1990.-С.306-307.

6. Сманцер А.П. Концептуальные основы преемственности в системе непрерывного образования / А.П. Сманцер. - Минск: изд-во БГУ, 1991. - $182 \mathrm{c}$.

\section{REFERENCES}

1. Basay, N. P. (2003). Dobriy den!: Kn. dlya vchitelya [Good day! Teacher's book]. Kyiv: Science, 87 p. [in Ukrainian].

2. Prohorova, A. M. (1973). Bolshaya sovetskaya entsiklopediya [Great Soviet Encyclopedia]. Moscov: Soviet Encyclopedia. Vol. 12, 875p. [in Russian].

3. Goncharenko, S. U. (1997). Ukrainskiy pedagogichniy slovnyk [Ukrainian Pedagogical Dictionary]. Kyiv: Libid, 374 p. [in Ukrainian].

4. Kustov, Y. A. (1989). Teoreticheskie osnovyi preemstvennosti professionalnoy podgotovki molodezhi [Theoretical foundations of the continuity of youth vocational training]. Kazan, 367p. [in Russian].

5. Batyisheva, S.Y (Ed.). (1990). Preemstvennost $v$ obuchenii. Entsiklopediya professionalnogo obrazovaniya: V 3-h $t$. [Continuity in learning. Encyclopedia of vocational education: In 3 tons]. Vol.2, Moscov: Professional education, pp. $306-$ 307p. [in Russian].

6. Smantser, A. P. (1991). Kontseptualnyie osnovyi preemstvennosti v sisteme nepreryivnogo obrazovaniya [Conceptual foundations of continuity in the system of continuous education]. Minsk: edition BGU, 182p. [in Russian].

Стаття надійшла до редакції 11.10.2018

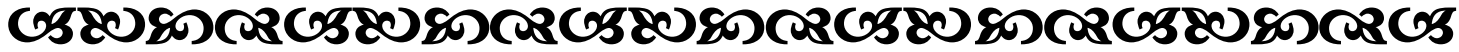

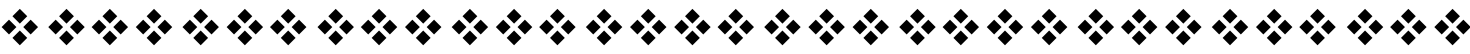

Молодь і ринок №11 (166), 2018 